\title{
PEMBERDAYAAN TANAH WAKAF SEBAGAI POTENSI EKONOMI UMAT DI MASJID AL-MARKAZ Al-ISLAMI MAKASSAR
}

\author{
Oleh: \\ Sirajuddin dan Asrum Yolleng \\ UIN Alauddin Makassar \\ e-mail: sirajuddinroy@gmail.com dan asrumjhe95@gmail.com
}

\begin{abstract}
ABSTRAK
Tujuan penelitian ini adalah untuk mengetahui program dan kegiatan pengelolaan tanah wakaf sebagai ekonomi potensi umat di mesjid al-Markaz alIslami Makassar, mengetahui metode pelaksanaan program pengelolaan tanah wakaf di masjid al- Markaz al-Islami Makassar, dan mengetahui hambatan dan tantangan dalam pemberdayaan tanah wakaf di mesjid al-Markaz al-Islami Makassar.

Jenis penelitian ini merupakan penelitian deskriptif kualitatif dengan pendekatan penelitian yang digunakan adalah pendekatan penelitian kualitatif. Adapun sumber data primer penelitian ini adalah pengurus yayasan Islamic center, Pengurus BPH, pedagang dan jamaah masjid. Selanjutnya metode pengumpulan data yang digunakan adalah observasi dan wawancara. Lalu, teknik pengolahan dan analisis data dilakukan dengan melalui empat tahapan, yaitu: reduksi data (data reduction), penyajian data (display data), analisis perbandingan (comparatif), dan penarikan kesimpulan (verivication).

Hasil penelitian ini menyimpulkan bahwa Masjid al-Markaz al-Islami Jenderal M. Jusuf dalam pengelolaannya memiliki beberapa program yang bersifat produktif. Menerapkan fungsi manajemen. Masala komunikasi dan dinamika pengurus. Kesimpulan: Masjid al-Markaz al-Islami Jenderal M. Jusuf dalam pengelolaannya memiliki beberapa program yang bersifat produktif. Misalnya, BMT al-Markaz, koperasi al-Markaz, penerbitan al-Markaz, Badan Pendidikan Islam, menyewakan ruangan aula yang ada di lantai I Masjid, menyewakan tokoh-tokoh buku dan pakaian yang ada di pelataran Masjid lantai I, sewa kanting al-Markaz, pasar jumat, basar ramadhan dan. Semua kegiatan pengelolaan Masjid al-Markaz al-Islami Jenderal M. Jusuf ini menunjukkan adanya produktivitas pengelolaan tanah wakaf. Implikasi: pengurus perlu meningkatkan profesionalisme. Perlu memaksimalkan fungsi manajemen. Dan perlu adanya usaha untuk menghadapi tantangan dan hambatan dalam pemberdayaan tanah wakaf.
\end{abstract}

Kata kunci: Wakaf; Produktivitas; Ekonomi Umat. 


\section{PENDAHULUAN}

Pembicaraan tentang persoalan ekonomi harta wakaf merupakan pembahasan yang menarik. Perwakafan atau wakaf merupakan pranata dalam keagamaan Islam yang sudah mapan. Wakaf termasuk ke dalam kategori ibadah. Sepanjang sejarah Islam, wakaf merupakan sarana dan modal yang amat penting dalam memajukan perkembangan agama. ${ }^{1}$

Wakaf di Indonesia dikenal dan dilaksanakan oleh umat Islam sejak agama Islam masuk ke Indonesia yang juga menjadi salah satu penunjang pengembangan agama dan masyarakat Islam. Masalah wakaf khususnya perwakafan tanah milik, jika dikaitkan dengan Undang-undang Nomor 5 Tahun 1960 tentang Peraturan Dasar Pokok Agraria adalah sangat penting, sehingga kemudian perlu diatur dalam Peraturan Pemerintah Nomor 28 Tahun 1977, tentang Perwakafan Tanah Milik yang kemudian dikuatkan dengan dikeluarkannya Undang-undang Nomor 41 Tahun 2004, tentang Wakaf dan Peraturan Pemerintah Nomor 42 Tahun 2006, sebagai aturan pelaksanaannya, sehingga wakaf tanah dapat digunakan sebagai salah satu sarana pengembangan penghidupan beragama dan bermasyarakat dan semakin luas dan kongkrit, khususnya bagi umat Islam dalam rangka mencapai kesejahteraan materiil dan sprituil menuju masyarakat adil dan makmur. ${ }^{2}$

Amalan wakaf termasuk salah satu amal yang paling disukai kaum muslimin disebabkan pahalanya yang terus menerus akan diterima si wakif walaupun ia telah meninggal dunia nanti. Karena itu cukup beralasan pendapat yang menyatakan bahwa amal wakaf itu telah masuk ke Indonesia bersamaan dengan masuknya agama Islam. Hal ini dapat diketahui dari tanahtanah tempat berdirinya Masjid-Masjid, langgarl-anggar, surau-surau dan

1 Departemen Agama, Perkembangan Pengelolaan Wakaf di Indonesia, (Jakarta: Proyek Peningkatan Zakat dan Wakaf Dirjen Bimas dan Penyelenggaraan Haji, 2003), h. 1.

2 Direktorat Jenderal Bimbingan Masyarakat Islam dan Penyelenggaraan Haki, Perkembangan Pengelolaan Wakaf di Indonesia (Jakarta: Proyek Pengelolaan Zakat dan Wakaf, 2003), h. 1. 
tempat-tempat pengajian kaum muslimin sebagai peninggalan kerajaankerajaan Islam zaman dahulu dan wakaf kaum muslimin sendiri, seperti yang terdapat diJawa, Sumatera, Kalimantan, Sulawesi dan di seluruh kepulauan Indonesia. Hanya saja pada waktu itu belum ada aturan yang formal dan pencatatan, semata-mata berdasarkan kepercayaan yang timbul di antara sesama kaum muslimin. ${ }^{3}$

Masa Rasulullah saw. masjid tidak hanya dijadikan sebagai tempat untuk beribadah saja, tetapi juga dijadikan sebagai tempat pendidikan, tempat latihan militer, pengobatan korban perang, tempat mendamaikan dan menyelesaikan sengketa dan bahkan dijadikan sebagai tempat pemberdayaan ekonomi umat seperti pengumpulan dan penyaluran harta zakat, infaq, sedeka, jizyah, kharaj, fay', tebusan tawanan perang dan lain-lain. Peran Masjid dengan baitul malnya sebagaimana dicontohkan para sahabat Rasulullah Saw. mengelola zakat, dapat dijadikan sebagai acuan dalam mengelola dana yang berasal dari zakat, infaq dan shadaqah dari masyarakat demi kesejahteraan masyarakat. Zakat merupakan instrumen yang paling efektif dan paling esensial dan tidak terdapat dalam sistem kapitalis maupun sosialis. Secara ekonomi zakat berfungsi distributif, yaitu pendistribusian kembali (redistribusi) pendapatan dari kaum berlebih kepada yang memerlukan, zakat memungkinkan adanya alokasi konsumsi dan investasi. ${ }^{4}$

Salah satu Masjid yang sangat berpotensi dan dinilai melakukan pemberdayaan ekonomi umat adalah Masjid al-Markaz al-Islami Makassar. Masjid yang terletak di daerah Makassar ini merupakan Masjid yang berpotensi melakukan program pemberdayaan umat khususnya dibidang ekonomi. Karena Masjid ini merupakan Masjid yang begitu megah dan memiliki manajemen yang baik maka orang-orang yang berpenghasilan tinggi (kaya)

3Zakiah Daradjat, Ilmu Figh, Jilid 3 (Yogyakarta: Dana Bhakti Wakaf, 1995), h. 21.

${ }^{4}$ Euis Amalia, keadilan Distributif dalam Ekonomi Islsm (Jakarta: Raja Grafindo Persada, 2009), h. 373-474. 
banyak yang tertarik untuk berkontribusi dalam membangun dan menjalankan program-program yang ada.

Bila luas tanah Masjid al-Markaz al-Islami Makassar adalah sepuluh ribu meter persegi sedangkan luas bangunannya enam ribu sembilan ratus tiga puluh dua meter persegi, maka masih tersisah lahan kosong seluas tiga ribu enam puluh delapan meter persegi. Lahan tanah kosong seluas tiga ribu enam puluh delapan meter persegi sebenarnya masih dapat di produktifkan misalnya dengan membangun sarana perekonomian dan semisalnya. Berangkat dari kenyataan ini, perlu dilakukan kajian lebih lanjut dan mendalam. Terdorong dari permasalahan di atas, maka penulis tertarik untuk melakukan penelitian dengan mengambil judul "Pemberdayaan tanah wakaf sebagai ekonomi umat di Masjid al-Markaz al-Islami Makassar.

\section{TINJAUAN TEORITIS}

\section{Tinjauan Umum Tentang Wakaf}

Secara etimologi kata wakaf berasal dari bahasa Arab waqf, kata kerjanya waqafa yaqifu, brarti berdiri, berhenti, ragu-ragu, menahan atau mencegah. Ungkapan kata waqaftu, berarti aku berdiri, aku berhenti, aku ragu-ragu, aku cegah dan aku tahan. Selanjutnya kata waqf lebih populer digunakan untuk makna mauquf, artinya yang ditahan, yang dihentikan atau yang diragukan, dibandingkan dengan makna suatu transaksi. ${ }^{5}$ Berdasarkan uraian di atas, maka yang dimaksud wakaf pada pembahasan kali ini adalah menahan harta benda untuk dimanfaatkan sesuai dengan yang dianjurkan oleh syariat Islam.

Adapun secara terminologi, terdapat beberapa pengertian yang di kemukakan oleh ulama diantaranya adalah Menurut Sayyid Sabiq, wakaf adalah menahan harta dan menggunakana manfaatnya di jalan Allah swt. ${ }^{6}$

${ }^{5}$ Mukhlisin Muzarie, Hukum Perwakafan dan Imlikasinya Terhadap Kesejahteraan Masyarakat (Implementasi Wakaf di Pondok Modern Darussalam Gontor) (Jakarta: Kementeran Agama RI 2010), h. 77.

${ }^{6}$ Abdur Rahman Ghazaly dkk, Fiqih Muamalat (Edisi I, Jakarta: Kencana Prenada Media Groub 2012), h. 175. 
Sedankan menurut Menurut Syaikh Abu Bakar Jabir al-Jaza'iri, wakaf adalah penahanan suatu harta sehingga harta itu tidak dapat diwariskan, dijual atau dihabiskan dan hasilnya diberikan kepada penerimanya. ${ }^{7}$

Kedua definisi dapat ditarik kesimpulan bahwa yang dimaksud dengan wakaf adalah penahanan suatu harta benda sehingga harta itu tidak dapat diwariskan, dijual atau dihabiskan dan menggunakana manfaatnya di jalan Allah swt.

Kunci dari keberhasilan wakaf terletak pada pengelolaan yang dilakukan oleh Nazhir. Nazhir dan tim kerjanya harus solid untuk memaksimalkan peran wakaf. ${ }^{8}$ Berjalan atau tidaknya tanah wakaf itu tergantung pada nasir karena nasir bertugas untuk mengelola wakaf tersebut, pengelolaan wakaf harus segera dilaksanakan dengan tidak menunda-nunda agar niat dari wakif untuk memanen pahala dapat terwujud, sehingga nasir harus benar-benar mengelola harta wakaf tersebut sesuai dengan peruntukannya.

Nasir juga mempunyai peran untuk mengumpulkan wakif sebayakbanyaknya, untuk pengelolaan harta benda wakaf agar dapat lebih tikembangkan tentu butuh modala yang besar, semakin banyak modal yang disiapkan maka semakin besar pula manfaat yang dapat dihasilkan dari harta benda wakaf trsebut.

Harta wakaf jika dikelola dengan baik dan sesuai dengan syariat maka harta wakaf yang dikumpulkan oleh sebuah lembaga wakaf dapat digunakan untuk memusnahkan riba. Ada beberapa contoh seperti untuk membangun pasar tradisional, untuk pengadaan timbangan modern, untuk membantu permodalan para pedagang, untuk membuat program penukaran uang receh menjelang hari raya, dan untuk program yang lain. Intinya, peran Nazhir sangat penting dalam memberdayakan harta wakaf. Inovasi program yang

\footnotetext{
${ }^{7} \mathrm{Abu}$ Bakar Jabir al-Jaza'iri, Minhajul Muslim, terj. Mustafa 'Aini dkk, Minhajul Muslim: Konsep Hidup Ideal dalam Islam (Jakarta: Darul Haq 2015), h. 736.

${ }^{8}$ Abdurrahman Kasdi, Wakaf Produktif Untuk Pendidikan (Yogyakarta: Idea Sejahtera, 2015), h. 48 .
} 
dibuat oleh Nazhir sangat menentukan keberhasilan peran harta wakaf dalam menghapuskan riba.

\section{Rukun dan Syarat Wakaf}

Ada beberapa rukun yang harus terpenuhi dalam perkara wakaf. Sebagaimana yang ditulis oleh Kurniati bahwa Rukun tersebut ada empat yaitu: ${ }^{9}$ (1) Orang yang berwakaaf (yang mewakafkan hartanya) atau yang disebut wakif (2) Harta yang diwakafkan atau maukuf (3) Tujuan wakaf atau yang berhak menerima hasil wakaf disebut maukuf'alaih (4) Pernyataan wakaf dari wakif yang disebut shighat atau ikrar wakaf.

Untuk lebih jelasnya penulis akan menguraikan ke empat rukun wakaf tersebut, sebagaimana yang ditulis oleh H. Sulaiman Rasjid adalah sebagai berikut:10 Ada yang berwakaf (wakif), syaratnya: (1) Berhak berbuat kebaikan, sekalipun dia bukan Islam dan (2) Kehendak sendiri; tidak sah karena dipaksa. Ada barang yang diwakafkann. Syaratnya: (1) Kekal zatnya. Berarti bila manfaatnya diambil, zat barang itu tidak rusak. (2) Kepunyaan yang mewakafkann, walaupun musya' (bercampur dan tidak dapat dipisaahkan daari yang lain). Sabda Rasulullah shallallahu 'alaihi wasallam:

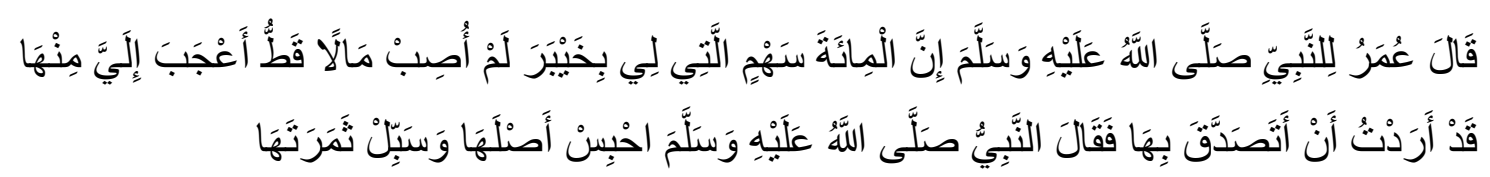

Artinya:

Umar telah berkata kepada Nabi shallallahu 'alaihi wasallam, "Sesungguhnya saya mempunyai seratus saham di Khaibar, belum pernah saya mempunyai harta yang lebih sayaa cintai dari pada itu. Sesungguhnya saya bermaksud menyedekahkannya". Jawab nabi shallallahu 'alaihi wasallam; "Engkau tahan pokoknya dan sedekahkanlah buahnya."

${ }^{9}$ Kurnia, Badaan Hukum Sebagai Wakaf Menurut Kompilasi Hukum Islam (Makassar: Alauddin University Press 2013), h. 66.

10Sulaiman Rasyid, Fiqh Islam (Bandung: Sinar Baru Algensido 2014), h. 341-342. 
Seratus saham kepunyaan Umar yang disebutkan dalam hadis di atas adalah musya'. Oleh karena itu, hadis ini menjadi dalil sahnya wakaf musya'.

Ada tempat berwakaf (yang berhak menerima hasil wakaf tersebut).

Kalau berwakaf kepada orang tertentu, orang yang berhak menerima hasil wakaf tersebut hendaknya orang yang berhak memiliki sesuatu. Maka tidak sah berwakaf padda anak yang masih dalam kandungan ibunya, begitu juga kepada hamba sahaya.

Ada beberapa syarat wakaf yang perlu diperhatikan. (1) Wakaf berlaku selamanya, tidak dibatasi oleh waktu tertentu. Jika ada yang mewakafkan kebun untuk jangka waktu sepuluh tahun maka dipandang batal. (2) Tujuan wakaf harus jelas, misaalanya mewakafkan sebidang tanah untuk mesjid. Jika, tujuan tidak disebutkan, maka masih dipandang sah sebab penggunaan harta wakaf merupakan wewenang lembaga hukum yang menerima harta wakaf. (3) Wakaf harus segera dilaksaanakan setelah ada ijab dari yang mewakafkan. (4) Wakaf merupakan perkara yang wajib dilaaksaanakan tanpa adanya khiyar (membatalkan atau melangsungkan wakaf yang telah dinyatakan) sebab pernyataan wakaf berlaku seketika dan untuk selamanya. ${ }^{11}$

Pendapat para ulama fiqhi mengenai batas waktu berlakunya wakaf ada dua pandangan. Pendapat yang pertama mengatakan bahwa wakaf berlaku selamanya dan kontiniu, pendapat ini dikemukakan oleh Imam Syafi'i, Imam Hanafi dan Imam Hanbali, karena jika wakaf ditentukan waktunya maka dipandang bukan wakaf sehingga di dalam hadis wakaf disebut sebagai shadaqah jariyah. Pendapat yang kedua mengatakan bahwa wakaf boleh disyaratkan dengan menentukan batas waktunya untuk jangka waktu tertentu, misalnya dengan batas waktu setahun atau dua tahun dan setelah sampai

${ }^{11}$ Abdur Rahman Ghazaly dkk, Fiqih Muamalat (Edisi I, Jakarta: Kencana Prenada Media Groub 2012), h. 179. 
waktu yang telah disyaratkan maka harta wakaf tersebut kembali pada pemiliknya semula, pendapat ini dikemukakan oleh Imam Malik. ${ }^{12}$

Wakaf itu diperbolehkan dengan tiga syarat: (1) Barang yang diwakafkan bisa dimanfaatkan dan keadaannya tetap utuh. (2) Barang yang diwakafkan sudah ada dan merupakan bagian yang tidak terpisah. (3) Barang yang diwakafkan bukan untuk perkara yang diharamkan.

Penggunaan harta wakaf harus mengikuti persyaratan orang yang mewakafkan entah itu mendahulukan, menunda, menyamakan, atau melebihkan (pemberian wakaf kepada sebagian dari pihak yang menerima wakaf). ${ }^{13}$

\section{Landasan Hukum Wakaf}

Telah menjadi ijma dikalangan ulama bahwa hukum mengeluarkan harta wakaf adalah sunnah, berdasarkan Firman Allah swt. dalam QS. Ali'Imran/3: 92.

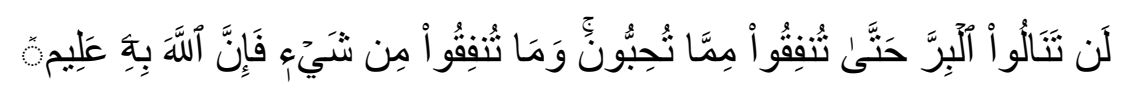

Terjemahnya:

Kamu tidak akan memperoleh kebajikan, sebelum kamu menginfakkan sebagian harta yang kamu cintai. Dan apa pun yang kamu infakkan, tentang hal itu sungguh, Allah maha mengetahui. ${ }^{14}$

Kata تُفْقُقْ pada ayat ini bermakna umum yakni apa saja yang di keluarkan secara sukarela, maka termasuk di dalamnya mengeluarkkan harta wakaf. Fitrahnya manusia mencinta apa yang dimilikinya dari harta dunia, ketika ia rela mengeluarkan apa yang ia cintai maka tentu balasan yang Allah 635-636.

12Muhammad Jawad Mughniyah, Fiqih Lima Mazhab (Jakarta: Penerbit Lentera, 2011), h.

${ }^{13}$ Abu Syuja' al-Ashfahani, Fikih Praktis Madzhab Syafi'i (Matan Abu Syuja') (Solo: Kuttab Punlishing, 2016), h. 191.

${ }^{14}$ Departemen Agama RI, Al-Qur'an dan Terjemahan (Bandung: PT. Syamil Cipta Media, 1428 H/2007 M), h. 62. 
Swt. janjikan juga begitu besar karena beratnya mengeluarkan harta benda yang kita cintai.

Berdasarkan sabda Rasulullah sallallahu 'alaihi wa sallam pada hadis yang lain. dari Abu Hurairah radiallahu 'anhu, bahwa Rasulullah sallallahu 'alaihi wa sallam. bersabda:

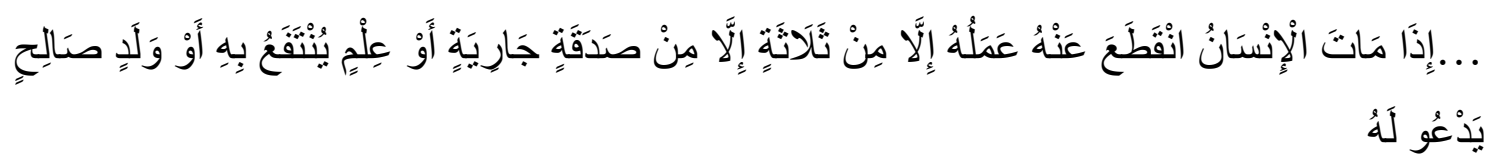

Artinya:

Jika seorang manusia meninggal dunia, maka terputuslah amal perbuatannya, kecuali tiga hal; sedekah jariyah, ilmu yang bermanfaat, dan anak shaleh yang selalu mendoakannya.

Diantara beberapa sedekah yang dikategorikan ke dalam sedekah jariyah adalah mewakafkan rumah, tanah, masjid dan lain-lain.

\section{Macam-Macam Wakaf}

Bila ditinjau dari segi peruntukan kepada siapa wakaf itu, maka wakaf dapat dibagi menjadi dua macam: (1) Wakaf Dzurri (Keluarga), Wakaf dzuri disebut juga wakaf khusus dan ahli ialah wakaf yang ditujukan untuk orangorang tertentu baik keluarga wakif atau orang lain. ${ }^{15}$ Jadi yang dapat menikmati manfaat benda wakaf ini sangat terbatas hanya kepada golongan kerabat sesuai dengan ikrar yang dikehendaki oleh si wakif. Dalam satu segi, wakaf ahli ini mempunyai dua aspek kebaikan, yaitu kebaikan sebagai amal ibadah wakaf dan kebaikan silaturrahmi terhadap keluarga yang diberikan harta wakaf. Namun, pada sisi lain wakaf ahli sering menimbulkan masalah, misalnya jika keturunannya terputus, tidak ada lagi pewarisnya atau keturunannya terlalu banyak, sehingga menyulitkan pengelolaannya dan pembagian hasilnya atau keturunan wakif tidak bersedia lagi mengurus harta wakaf dan seterusnya.

${ }^{15}$ Abdur Rahman Ghazaly dkk, Fiqih Muamalat (Edisi I, Jakarta: Kencana Prenada Media Groub 2012), h. 179. 
Perkembangan selanjutnya, wakaf ahli untuk saat ini dianggap kurang dapat memberikan manfaat bagi kesejahteraan umum, karena sering menimbulkan kekaburan dalam pengelolaan dan pemanfaatan wakaf oleh keluarga yang diserahi harta wakaf. (2) Wakaf Khairi, Wakaf khairi adalah wakaf yang ditujukan untuk kepentingan umum dan tidak dikhususkan kepada orang-orang tertentu. ${ }^{16}$ Wakaf ini ditujukan untuk kepentingan umum dengan tidak terbatas pada aspek penggunannya yang mencakup semua aspek untuk kepentingan dan kesejahteraan umat manusia pada umumnya. Kepentingan umum tersebut bisa untuk keagamaan, jaminan sosial, pendidikan, kesehatan, keamanan dan lain-lain, yang dapat berwujud seperti pembangunan masjid, sekolah, jembatan, rumah sakit, panti asuhan anak yatim dan sarana sosial lainnya.

Telah banyak kita saksikan harta wakaf yang sangat mempengaruhi perkembangan ekonomi umat, bahkan harta wakaf pada zaman Rasulullah Saw. masih ada sampai sekarang, seperti mesjid Quba dan mesjid Nabawi di Madinah, manfaat yang diberikan untuk umat sampai pada saat ini tentu sangatlah banyak.

\section{Tujuan dan Fungsi Wakaf}

Wakaf bertujuan memanfaatkan benda wakaf sesuai dengan fungsinya, dan wakaf berfungsi mewujudkan potensi dan manfaat ekonomi harta benda wakaf untuk kepentingan ibadah dan untuk memajukan kesejahteraan umum. ${ }^{17}$ Wakaf ini jika dapat dimaksimalakan dengan baik sesuai dengan tujuan dan fungsinya maka, sangat berpotensi untuk menopang kesejahteraan umat.

${ }^{16}$ Abdur Rahman Ghazaly dkk, Fiqih Muamalat (Edisi I, Jakarta: Kencana Prenada Media Groub 2012), h. 180.

${ }^{17}$ Mardani, Fiqih Ekonomi Syariah (Jakarta: Kencana Prenada Media Groub 2013), h. 357. 


\section{METODE PENELITIAN}

Jenis penelitian ini merupakan penelitian deskriptif kualitatif dengan pendekatan penelitian yang digunakan adalah pendekatan penelitian kualitatif. Adapun sumber data primer penelitian ini adalah pengurus yayasan Islamic center, Pengurus BPH, pedagang dan jamaah masjid. Selanjutnya metode pengumpulan data yang digunakan adalah observasi dan wawancara. Lalu, teknik pengolahan dan analisis data dilakukan dengan melalui empat tahapan, yaitu: reduksi data (data reduction), penyajian data (display data), analisis perbandingan (comparatif), dan penarikan kesimpulan (verivication). 18 Pengambilan sampel menggunakan beberapa teknik pengumpulan data: Observasi, wawancara, studi Pustaka, dokumentasi. Instrument penelitian adalah peneliti itu sendiri. ${ }^{19}$ Oleh karena itu peneliti sebagai instrument juga harus divalidasi, seberapa jauh peneliti siap melakukan penelitian untuk selanjutnya terjun ke lapangan. Analisis data dalam penelitian ini reduksi data, penyajian data, penarikan kesimpulan.

${ }^{18}$ Ahmad Tanzeh, Pengantar Metode Penelitian, (Yogyakarta: Teras, 2009), h. 53.

${ }^{19 S}$ Sugiyono, Memahami Penelitian Kualitatif (Bandung: CV Alfabeta, 2008) h, 59. 


\section{HASIL PENELITIAN DAN PEMBAHASAN}

\section{Program dan Kegiatan Pengelolaan Tanah Wakaf Sebagai Ekonomi Umat}

Masjid al-Markaz al-Islami Jenderal M Jusuf memiliki banyak program dan kegiatan dalam mengelolah tanah wakaf, baik itu berupa pembangunan fisik, program dan kegiatan BPH dakwah, wakaf dan kajian Islam, program kegiatan ekonomi dan kegiatan lainnya.

Badan Pengelola Harian (BPH) dakwah, wakaf dan kajian Islam adalah salah satu BPH masjid al-markaz al-Islami jenderal M.Yusuf yang fungsi utamanya mengurusi khatib dan muballigh serta kegiatan dakwah di masjid alMarkaz al-Islami Jenderal M. Jusuf. Badan Pengelola Harian (BPH) dakwah, wakaf dan kajian Islam memiliki struktur kepengurusan yang masing-masing kepengurusan memiliki program kegiatan tersendiri. Sebagaimana diungkapkan oleh ibu Asni Tayyib selaku bendahara di Badan Pengelola Harian (BPH) Yayasan Islamic Center:

Di yayasan ini ada BPH-nya (Badan Pengelola Harian) dan masingmasing $\mathrm{BPH}$ ada prograng tersendirinya, jadi program kerja itu tergantung pada $\mathrm{BPH}-\mathrm{BPH}$ nya. ${ }^{20}$

Masing-masing BPH telah disiapkan anggaran untuk setiap program yang akan dilaksanakan sehingga program itu dibuat sesuai dengan anggaran yang disediakan. Rais badan takmir al-markaz al-Islami, Rahman Getteng, mengatakan sebagai berikut:

Masing-masing BPH (Badan Pengelola Harian) itu conditional, karena masing-masing BPH itu disiapkan anggaran untuk melakukan aktivitas, kalau ada programnya itu ditinjau dari anggaran. ${ }^{21}$

Masjid al-Markaz al-Islami memiliki banyak program dan di antara program-program pengurus memiliki program-program yang bersifat ekonomi

${ }^{20}$ Asni Tayyib(78 tahun), Bendahara BPH Yayasan Islamic Center, Wawancara, Lantai 1 Masjid al-Markaz al-Islami Jenderal M. Jusuf, Makassar, 27 November 2017.

${ }^{21} \mathrm{H}$. Abd. Rahman Getteng (75 tahun), Rais Badan Takmir al-markaz al-Islami, Wawancara, Lantai dasar (Kantor) masjid al-markaz al-Islami jenderal M. Jusuf, Makassar, 8 Desember 2017. 
dan produktif. Adapun program dan kegiatan pengelolaan tanah wakaf yang bersifat ekonom di Masjid al-Markaz al-Islami Makassar adalah sebagai berikut: (1) Baitul Maal Wattamwil (BMT) al-Markaz, Baitul Maal Wattamwil (BMT) alMarkaz merupakan lembaga keuangan Masjid al-Markaz yang telah berjalan dan bertempat di Masjid al-Markaz lantai satu. Dana awal dari BMT al-Markaz ini diambil dari pengurus dan jamaah Masjid al-Markaz yang sekaligus sebagai pendiri BMT al-Markaz. (2) Koperasi al-Markaz (KOPMAZ), Koperasi alMarkaz (KOPMAZ) sebagai lembaga keuangan Masjid al-Markaz ini juga telah berjalan.

Jumlah pengurus Koperasi al-Markaz (KOPMAZ) saat ini hanya delapan orang. Adapun unit usaha Koperasi al-Markaz (KOPMAZ) adalah seperti Wartel, mini swalayan, counter baju muslim, foto copy/ATK, kredit barang, sewa gedung, loket PDAM/PLN on line, vocher pulsa, rental pengetikan komputer dan warnet. (3) Badan Pendidikan Islam, Badan pendidikan islam ini memiliki beberapa program pendidikan yang telah berjalan sperti Taman Kanak-Kanak (TK), Taman Baca Al-quran (TPA), Pendidikan Anak Usia Dini (PAUD) dan kursus bahasa (bahasa Arab dan bahasa Ingris). Program dan kegiatan pendidikan Islam ini di tangani oleh pengurus Badan Pengelolaan Harian (BPH) Dakwah, Wakaf dan Kajian Islam. (4) Penyewaan Gedung Aula, Gedung Aula Masjid al-Markaz terletak di lantai I Masjid, tempat ini disewakan untuk kegiatan-kegiatan resmi seperti pesta perkawinan, pameran san lain-lain. Dengan tarif mulai tiga ratus ribu rupiah dan ada dispensasi pengurangan harga sewa untuk lembaga atau organisasi. (5) Penyewaan Tempat Tokoh Buku dan Pakaian, Masjid al-Markaz menyewakan tempat untuk tokoh buku dan pakaian beserta menyewakan tempat untuk kanting. Pelataran lantai I Masjid al-Markaz disewakan untuk toko-toko buku dan pakaian. Tarif perbulannya sebesar lima ratus ribu sampai enam ratus ribu rupiah. Hal ini dikatakan oleh pak Padli Zainal seorang penjaga tokoh di Masjid al-Markaz: 
Saya menyewa tempat di sini, sewa perbulannya Rp 500.000.00 sampai Rp 600.000.00 tergantung dengan luasnya tempat yang di gunakan. Selama jualan di sini yah.. al-hamdulillah adalah.. untung yang saya dapat. ${ }^{22}$

(6)Pasar Jumat dan Basar Ramadhan, Waktu pelaksanaan pasar jumat iyalah tiap pekannya tepatnya pada hari jumat, banyaknya jamaah yang dapat ditampung pada masjid al-Markaz menjadikan para pedagang tertarik, bahkan begitu banyak yang berdatangan. Sehingga dimanfaatkanlah keadaan tersebut dengan membayar infaq pada tiap pedagang dengan senilai lima ribu rupiah sampai sepuluh ribu rupiah. Basar ramadhan dilaksanakan hanya pada bulan Ramadhan saja, karena bulan Ramadhan jamahnya sangat banyak sehingga memancing para pedagang untuk masuk ke Masjid al-Markaz untuk berdagang.

\section{Metode Pelaksanaan Program Pengelolaan Tanah Wakaf}

Metode atau cara pelaksanaan program-program pengelolaan tanah wakaf memiliki kaiatan yang sangat erat dengan fungsi manajemen, dimana tata cara pelaksanaan suatu program dapat tergambar dengan jelas melalui fungsi manajemen. Tujuan pelaksanaan suatu program tidak terlepas dari tujuan suatu lembaga, sebagaimana tujuan dari pelaksanaan fungsi manajemen ini ialah agar supaya program-program dapat terlaksana dengan baik dan tertip sesuai dengan tujuan suatu lembaga.

Pengertian manajemen telah banyak dibahas para ahli yang antara satu dengan yang lain saling melengkapi. Stoner yang dikutip oleh Handoko menyatakan bahwa manajemen merupakan proses perencanan, pengorganisasian, pengarahan, dan pengawasan, usaha-usaha para anggota organisasi dan pengguna sumber daya organisasi lainya untuk mencapai tujuan organisasi yang telah ditetapkan. Stoner menekanan bahwa manajemen dititik beratkan pada proses dan sistem. Oleh karena itu, apabila dalam sistem dan proses perencanaan, pengorganisasian, pengarahan, penganggaran, dan

22Padli Zainal (26 tahun), Penjaga Tokoh di Masjid al-Markaz al-Islam Jenderal M. Jusuf, Wawancara, Lantai 1 Masjid al-Markaz al-Islami Jenderal M. Jusuf, Makassar, 01 Desember 2017. 
sistem pengawasan tidak baik, proses manajemen secara keseluruhan tidak lancar sehingga proses pencapaian tujuan akan terganggu atau mengalami kegagalan. ${ }^{23}$

Fungsi manajemen dapat dibagi menjadi empat bagian, yakni planning (perencanaan), organizing (pengorganisasian), actuating (pelaksanaan), dan controlling (pengawasan). ${ }^{24}$ Terlaksananya fungsi manajemen tersubut tentu dapat mendukung terlaksananya suatu tujuan pada lembaga, maka dari itu penulis akan membahas satu-persatu terkait dengan pelaksanaan fungsi manajemen dari yang empat tersebut dalam pengelolaan tanah wakaf di Masjid al-Markaz al-Islami J. M Jusuf:

Pertama: Perencanaan (planning), Penentuan segala sesuatunya terlebih dahulu, untuk melaksanakan suatu kegiatan dan aktivitas, itulah yang disebut dengan istilah "planning". Adapun definisi planning sebagai berikut: "planning is deciding inadvance what is to be done" 25 planning adalah penentuan terlebih dahulu apa yang akan di kerjakan. Sebagaimana yang dikatakan oleh G.R. Terry, Planning atau perencanaan adalah tindakan memilih dan menghubungkan fakta dan membuat serta menggunakan asumsi-asumsi mengenai masa yang akan datang dalam hal menvisualisasikan serta merumuskan aktivitas-aktivitas yang diusulkan yang dianggap perlu untuk mencapai hasil yang diinginkan. ${ }^{26}$ Penentuan ini juga merencanakan tindakan secara efektif dan efesien dan mempersiapkan input dan output.

Tanah wakaf seluas 10 ha sebenarnya telah direncanakan untuk membangun di atasnya tiga fasilitas yaitu Masjid, Auditorium dan komleks sekolah. Keterbatasan luas lahan menjadi sebab akhirnya diputuskan

${ }^{23}$ Syihabuddin Qalyubi, dkk., Dasar-Dasar Ilmu Perpustakaan dan Informasi (Yogyakarta: Jurusan Ilmu Perpustakaan dan Informasi (IPI) Fakultas Adab UIN Sunan Kalijaga 2007), h. 271.

${ }^{24}$ George R.Terry dan Leslie W.Rue, Dasar-Dasar Manajemen. (Jakarta: Bumi Aksara, 2010), h. 9.

${ }^{25}$ Willian H. Newman, Administrative Action (Prentice: Engliwood, 1975), h. 15.

${ }^{26}$ Ngalim Purwanto, Ilmu Pendidikan Teoritis Dan Praktis (Bandung: Remaja Rosda Karya, 2006), h. 45. 
auditorium tidak jadi dibangun dan sebagai gantinya lantai I Masjid dirubah tata letaknya sehingga dapat berfungsi sebagai Aula. Sedangkan kompleks sekola direncanakan akan dibangun pada tahap ke II. Sebagaimana diungkapkan oleh ibu Asni Tayyib selaku bendahara di Badan Pengelola Harian (BPH) Yayasan Islamic Center:

Sebelah Masjid al-Markaz ini ada tanah kosong, luasnya kira-kira lebih dari 3 ha, disitu nantinya akan dibanguni kompleks sekolah. Gambarnya bisa dilihat di perpustakaan. Peletakan batu pertamanya di bulan oktober lalu dilaksanakan. ${ }^{27}$

Program kerja dan program kegiatan yang sebelumnya telah disusun secara musyawarah pada setiap Badan Pengelola Harian (BPH) adalah merupakan sebuah bentuk dari perencanaan (planning) itu sendiri, sehingga telah terlihat dengan jelas bahwa dibuatnya program kerja dan program kegiatan tersebut tentu mengacu pada tujuan suatu lembaga.

Kedua: Pengorganisasian (organizing), Setelah menetapkan tujuantujuan dan menyusun rencana-rencana atau program-program untuk mencapai tujuan lembaga, maka mereka perlu merancang dan mengembangkan suatu organisasi yang akan dapat melaksanakan berbagai program tersebut secara sukses.

Pengorganisasian adalah proses yang menyangkut bagaimana strategi dan taktik yang telah dirumuskan dalam perencanaan didesain dalam sebuah struktur organisasi yang tepat dan tangguh, sistem dan lingkungan organisasi yang kondusif, dan bisa memastikan bahwa semua pihak dalam organisasi bisa bekerja secara efektif dan efesien guna pencapaian tujuan. Organizing adalah pengorganisasian atau dalam istilah bahasa arabnya disebut al-tanzim.

Pengorganisasian (organizing) adalah 1) penentuan sumber daya sumber daya dan kegiatan-kegiatan yang dibutuhkan untuk mencapai tujuan organisasi, 2) perancangan dan pengembangan suatu organisasi kelompok kerja yang akan dapat membawa hal-hal tersebut kearah tujuan., 3) penugasan

${ }^{27}$ Asni Tayyib(78 tahun), Bendahara BPH Yayasan Islamic Center, Wawancara, Lantai 1 Masjid al-Markaz al-Islami Jenderal M. Jusuf, Makassar, 01 Desember 2017. 
tanggung jawab tertentu dan kemudian, 4) pendelegasian wewenang yang diperlukan kepada individu-individu untuk melaksanakan tugas-tugasnya. Fungsi ini menciptakan struktur formal dimana pekerjaan ditetapkan, dibagi dan dikoordinasikan. ${ }^{28}$

Dari beberapa pengertian ini, maka organizing merupakan faktor yang sangat menentukan sekali dan erat kaitannya dengan planning yang telah jadi patokan, didalam menggerakan orang guna mencapai tujuan. Karena kelompok itu sendiri terdiri dari beberapa orang, maka kerjasama yang terpadu antara semua itu merupakan bagian yang menentukan, dengan demikian tindakan organizing, merupakan unsur yang sangat mendasar.

Masjid al-markaz al-Islami jenderal M. Jusuf bernaung di bawah Yayasan Islamic Center. Yayasan ini kemudian membentuk pengurus masjid yang terdiri atas sejumlah Badan Pegelola Harian (BPH) yaitu: BPH Dakwah, wakaf dan Kajian Islam, BPH Perempuan dan Majelis Taklim, BPH Keuangan dan Ekonomi, BPH Pelatihan dan Litbang, BPH Keamanan dan Hukum, BPH Humas, BPH Sosial Kemasyarkatan, BPH Sarana dan Prasarana, BPH Pemuda, Olahraga dan Kesenian, BPH Arsip dan Perpustakaan. ${ }^{29}$

Struktur kepengurusan Masjid al-markaz al-Islami jenderal M. Jusuf adalah merupakan bentuk dari pengorganisasian. Adanya kerja sama antara yang satu dengan yang lainnya dengan membagi kelompok-kelompok yang tepat dan menempatkan seseorang pada bidang keahliannya masing-masing menunjukkan adanya lingkungan organisasi yang kondusif, sehinngga tujuan organisasi dapat tercapai.

Ketiga: Pelaksanaan (actuating), Pelaksanaan adalah menerapkan program agar bisa dijalankan oleh seluruh pihak dalam organisasi serta proses memotivasi agar semua pihak tersebut dapat menjalankan tanggung jawabnya dengan penuh kesadaran dan produktivitas yang tinggi. Pelaksanaan

\footnotetext{
${ }^{28}$ Sukanto Reksohadiprojo dan T. Hani Handoko, Organisasi Perusahaan: Teori, Struktur dan Perilaku (Yogyakarta: BPFE, 1999), h. 24.

${ }^{29}$ Anwar Arifin, Jurnal Ilmiah Keislaman al-Markaz, (Makassar: BPH Yayasan Masjid alMarkaz al-Islami Jenderal M. Jusuf, 2005), h. 36.
} 
(actuating) ini memiliki kaitan yang erat dengan Perencanaan (planning) dan pengorganisasian (organizing), karena setelah adanya perencanaan dan pengorganisasian haruh ada pelaksanaannya.

Pengertian pelaksanaan (actuating) adalah membuat semua anggota organisasi mau bekerja sama dan bekerja secara ikhlas serta bergairah untuk mencapai tujuan sesuai dengan perencanaan dan usaha-usaha pengorganisasian. ${ }^{30}$

Pelaksanaan program kerja dan program kegiatan di Masjid al-Markaz al-Islami itu belum terlaksa secara maksimal, akan tetapi tidak ada BPH yang tidak melaksanakan kegiatan, karena BPH yang satu dengan yang lain itu ada yang bekerja secara rutin dan ada yang tidak, tergantung pada pekerjaan BPHnya masing-masing. Hal ini dikatakan oleh Abd. Rahman Getteng, Rais badan takmir al-markaz al-Islami, bahwa:

Yang namanya lembaga itu pasti ada kelebihan dan ada kelemahannnya. Kelemahannya iyalah ada BPH yang belum melaksanakan perogramnya secara maksimal, ada yang melaksanakan dan ada yang lebih dari pada yang lain, tapi tidak ada BPH yang tidak melaksanakan kegiatan. Perbedaan dengan BPH satu dengan yang lain, katakanlah BPH ibadah karena memanng dia menangani masalah ibadah secara rutin, BPH Ekonomi terus-menerus, BPH Perempuan melaksanakann juga, BPH Sarana dan Prasarana itu melihat kondisi jika ada yang mau diperbaiki atau mau dikembangkan, ada BPH yang bekerja secara rutin karena memang sifat pekerjaannya berhadapan dengan manusia seperti $\mathrm{BPH}$ Ibadah. ${ }^{31}$

Keempat: Pengendalian dan pengawasan (controling), Pengendalian (pengawasan) atau controling adalah bagian terakhir dari fungsi manajemen. Fungsi manajemen yang dikendalikan adalah perencanaan, pengorganisasian, pengarahan, dan pengendalian itu sendiri. ${ }^{32}$ Proses ini dilakukan untuk 2006), h. 58.

${ }^{30}$ Ngalim Purwanto, Ilmu Pendidikan Teoritis Dan Praktis (Bandung: Remaja Rosda Karya,

${ }^{31}$ H. Abd. Rahman Getteng (75 tahun), Rais Badan Takmir al-markaz al-Islami, Wawancara, Lantai dasar (Kantor) masjid al-markaz al-Islami jenderal M. Jusuf, Makassar, 8 Desember 2017.

${ }^{32}$ Husaini Usman, Manajemen: Teori, Praktik, dan Riset Pendidikan, (Jakarta: PT Bumi Aksara, 2010), h. 503. 
memastikan seluruh kegiatan yang telah dirancang dari awal bisa berjalan dengan target yang diharapkan. ${ }^{33}$

Pengendalian (pengawasan) atau controling bersumber dari tauhid dan keimanan kepada Allah swt. seseorang yang yakin bahwa Allah pasti mengawasi hambanya, maka ia akan bertindak hati-hati ketika sendiri, ia yakin bahwa Alloh yang kedua, dan ketika berdua, ia yakin Alloh yang ketiga, juga merupakan salah satu dari keyakinan umat Islam, bahwasanya Allah Swt. senantiasa mengawasi seluruh mahluknya. Allah swt. berfirman dalam QS. alMujādilah/58: 7.

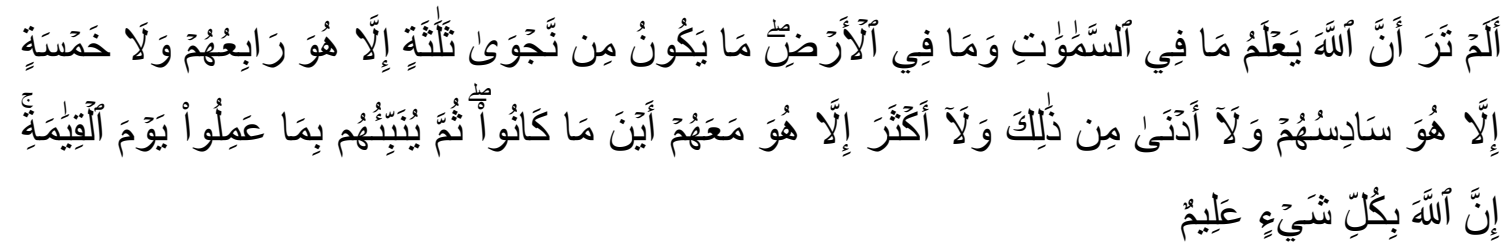

Terjemahnya:

Tidakkah kamu perhatikan, bahwa Sesungguhnya Allah mengetahui apa yang ada di langit dan di bumi? Tiada pembicaraan rahasia antara tiga orang, melainkan Dia-lah keempatnya. Dan tiada (pembicaraan antara) lima orang, melainkan Dia-lah keenamnya. dan tiada (pula) pembicaraan antara jumlah yang kurang dari itu atau lebih banyak, melainkan Dia berada bersama mereka di manapun mereka berada. kemudian Dia akan memberitahukan kepada mereka pada hari kiamat apa yang telah mereka kerjakan. Sesungguhnya Allah Maha mengetahui segala sesuatu. ${ }^{34}$

Pengendalian dan pengawasan senantiasa dilakukan, apakah dari yayasan Islamic center, dari koordinator BPH/ ketua BPH ataupun dari jamaah itu sendiri. Oleh karenanya aspirasi dari jamaah menjadi salah satu bahan pertimbangan untuk evaluasi selanjutnya. Biasa juga disebarkan angket kepada jamaah untuk mengetahui pendapat mereka mengenai kualitas dan kinerja seorang muballigh. Bentuk pengawasannya bisa berupa surat teguran secara 2008), h. 8.

${ }^{33}$ Ernie Tisnawati Sule dan Kurniawan Saefullah, Pengantar Manajemen (Jakarta: Kencana,

${ }^{34}$ Departemen Agama RI, Al-Qur'an dan Terjemahannya, (Jakarta: Departemen Agama RI, 1971), h. 909. 
langsung. Rais badan takmir al-markaz al-Islami, Abd. Rahman Getteng, mengatakan sebagai berikut:

Bentuk pengawasan ada dalam stegmen-stegmen tertulis dan ada teguran secara langsung. Pengawasannya sesuai dengan kondisi BPH, kalau bidan ekonomi yaa dilihat perkembangan-perkembangannya, kalau ada misalnya BPH yang melakukan kegiatan-kegiatan di luar pengendalian Masjid yaa itu dicegah oleh Yayasan. ${ }^{35}$

\section{Hambatan dan Tantangan Dalam Pemberdayaan Tanah Wakaf}

Setiap lembanga atau organisasi tidak akan pernah terlepas dari hambatan dan tantangan, sehingga semuanya mesti mempersiapkan diri untuk menghadapinya. Mengamati hambatan dan tantangan pada suatu lembaga merupakan hal yang sangat penting, karena yang demikian tersebut menyangkut keberlangsungan sebuah lembaga, dengan mengetahui apa saja hambatan yang akan dilalui dan tantangan yang akan dihadapi maka akan menjadikan suatu lembaga untuk bersiap siaga untuk menghadapi hambatan dan tantangan tersebut. Hambatan dan tantangan yang telah dianalisis suatu lembaga akan menjadikan lembaga untuk membuat solusi yang jitu untuk menangani setiap tantangan dan hambatan tersebut.

Analisis SWOT merupakan teori yang sangat efektif untuk mengetahui hambatan dan tantangan suatu lembaga dan bahkan teori ini dapat secara langsung memberikan sebuah solusi yang sangat baik pada setiap hambatan dan tantangan yang dihadapi oleh lembaga atau instansi. Solusi tersebut dapat tergambar dengan adanya analisis terhadap peluang dan analisis terhadap kekuatan suatu lembaga maka dengan sendirinya baik berupa ancaman maupun kelemahan dapat tertutupi dengan mengetahui peluang dan kekuatan pada lembaga atau instansi.

${ }^{35} \mathrm{H}$. Abd. Rahman Getteng (75 tahun), Rais Badan Takmir al-markaz al-Islami, Wawancara, Lantai dasar (Kantor) masjid al-markaz al-Islami jenderal M. Jusuf, Makassar, 8 Desember 2017. 
Kata SWOT merupakan pendekatan dari Strenghts, Weakness, Opportunity, and Threats, yang dapat diterjemahkan menjadi : Kekuatan, Kelemahan, Peluang dan Ancaman. ${ }^{36}$ Analisis SWOT membandingkan antara faktor eksternal Peluang (opportunities) dan Ancaman (threats) dengan faktor internal Kekuatan (strengths) dan Kelemahan (weaknesses). Analisis SWOT inilah yang akan kita gunakan untuk mengetahui hambatan dan tantangan dalam pemberdayaan tanah wakaf sekaligus untuk mengetahui solusinya.

Pertama: Internal, Analisis lingkungan internal disebut juga analisis kekuatan dan kelemahan organisasi/perusahaan, analisis kapabilitas dan budaya organisasi, atau kadang juga disebut analisis jati diri organisasi/perusahaan merupakan analisis mengenai sumberdaya perusahaan, dan peluang-peluang industri. ${ }^{37}$

Adapun strenght ( kekuatan ) dan weaknesses ( kelemahan ) dalam pemberdayaan tanah wakaf di Masjid al-Markaz al-Islami Jenderal M. jusuf adalah sebagai beerikut: (a) Strenght ( kekuatan), Strenght ( kekuatan ) yang ada dalam pemberdayaan tanah wakaf di Masjid al-Markaz al-Islami Jenderal M. jusuf dari segi sudut pandang sumber daya manusianya (SDM) adalah adanya kekompakan dan kerjasama dalam menjalankan program kegiatan pengelolaan tanah wakaf dan juga jika dilihat dari sisi manajemen keorganisasiannya pun cukup bagus. (b) Weaknesses ( kelemahan ), Weaknesses ( kelemahan ) yang ada dalam pemberdayaan tanah wakaf di Masjid al-Markaz al-Islami Makassar dari segi sudut pandang keuangan iyalah dana yang di dapatkan Badan Pengelolaan Harian (BPH) dakwah, wakaf dan kajian Islam sudah dianggarkan dalam anggaran masjid dan biasa terkendala masalah itu karena persoalan komunikasi. Kelemahan yang lainnya adalah belum dirumuskannya visi dan misi Masjid al-Markaz al-Islami Makassar secara terperinci.

Kedua: Eksternal, Lingkungan Eksternal bisa dikatakan sebagai komponen-komponen atau variabel lingkungan yang berada atau berasal dari

\footnotetext{
36Indriyo Gitosudarmo, Manajemen Keuangan (Cet. II; Yogyakarta: BPFE, 2001), H. 115.

${ }^{37}$ RD Jatmiko, Manajemen Strategik (Malang: UMM Press, 2004), h. 68.
} 
luar organisasi/perusahaan. Komponen tersebut cendrung berada di luar jangkauan organisasi, artinya organisasi/perusahaan tidak bisa melakukan intervensi terhadap komponen-komponen tersebut. Komponen itu lebih cenderung diperlukan sebagai sesuatu yang given atau sesuatu yang mau tidak mau harus diterima, tinggal bagaimana organisasi berkompromi atau menyiasati komponen-komponen tersebut. ${ }^{38}$

Adapun opportunity (peluang) dan threat (ancaman) dalam pemberdayaan tanah wakaf di Masjid al-Markaz al-Islami Makassar adalah sebagai berikut: (a) Opportunity (peluang), Banyaknya jamaah Masjid al-Markaz al-Islami Jenderal M. Jusuf yang memberikan loyalitasnya baik dari segi finansial maupun secara fisik dan luasnya tanah wakaf menjadikan Masjid alMarkaz al-Islami Jenderal M. Jusuf sebagai potensi ekonomi umat, selain itu jumlah jamaah yang sangat banyak memberikan peluang untuk menjadikan Masjid al-Markaz al-Islami Jenderal M. Jusuf sebagai pusat pembinaan jamaah. (b) Threat ( ancaman ), Faktor sosial dan politik menjadi dinamika persaingan antara Badan Pengelolaan Harian (BPH) dan pengurus lainnya selain itu, Badan Pengelolaan Harian (BPH) Dakwah, Wakaf dan Kajian Islam harus berfaham Islam moderat menjadi ancaman bagi Masjid al-Markaz al-Islami Jenderal M. Jusuf.

Demikianlah analisis SWOT pada pemberdayaan tanah wakaf di Masjid al-Markaz al-Islami Jenderal M. Jusuf, untuk lebih jelasnya perhatikanlah tabel berikut:

${ }^{38}$ Crown Dirgantoro, Manajemen Stratejik: Konsep, Kasus, dan Implementasi (Jakarta: PT Gramedia, 2004), h. 40. 


\begin{tabular}{|c|c|}
\hline EKSTERNAL & INTERNAL \\
\hline OPPORTUNITY ( PELUANG) & STRENGHT ( KEKUATAN ) \\
\hline $\begin{array}{l}\text { 1. Masjid al-markaz al-Islami } \\
\text { jenderal M. Jusuf memiliki } \\
\text { potensi ekonomi umat. } \\
\text { 2. Menjadikan Masjid al-markaz } \\
\text { al-Islami jenderal M. Jusuf } \\
\text { sebagai pusat pembinaan } \\
\text { jamaah. }\end{array}$ & $\begin{array}{l}\text { 1. Adanya kekompakan dan } \\
\text { kerjasama dalam } \\
\text { menjalankan program } \\
\text { kegiatan pengelolaan tamah } \\
\text { wakaf. } \\
\text { 2. Masjid al-Markaz memiliki } \\
\text { manajemen organisasi yang } \\
\text { bagus. }\end{array}$ \\
\hline $\begin{array}{l}\text { THREAT ( ANCAMAN) } \\
\text { 1. Dimanika persaingan antara } \\
\text { BPH dan pengurus yang lain } \\
\text { 2. BPH dakwah wakaf dan } \\
\text { kajian Islam harus berfaham } \\
\text { islam moderat }\end{array}$ & 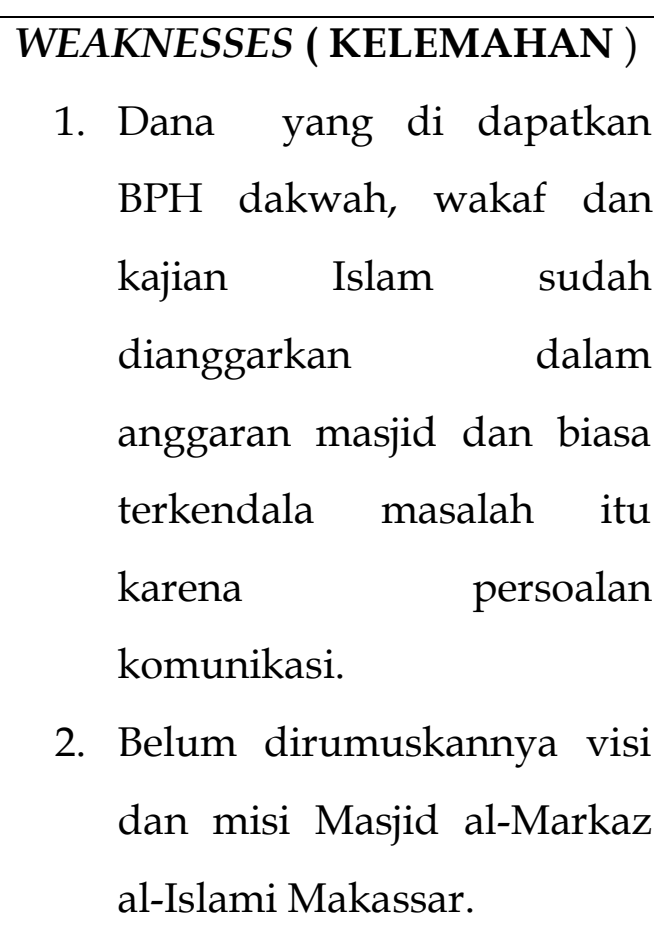 \\
\hline
\end{tabular}




\section{PENUTUP}

Berdasarkan hasil penelitian menenai pemberdaan tanah wakaf di masjid al-Markaz al-Islami Makassar, maka dapat diambil kesimpulan sebagai berikut: Masjid al-Markaz al-Islami Jenderal M. Jusuf dalam pengelolaannya memiliki beberapa program yang bersifat produktif seperti, BMT al-Markaz, koperasi al-Markaz, penerbitan al-Markaz, Badan Pendidikan Islam, menyewakan ruangan aula yang ada di lantai I Masjid, menyewakan tokohtokoh buku dan pakaian yang ada di pelataran Masjid lantai I, sewa kanting alMarkaz, pasar jumat, basar ramadhan dan semua kegiatan pengelolaan Masjid al-Markaz al-Islami Jenderal M. Jusuf ini menunjukkan adanya produktivitas pengelolaan tanah wakaf.

Kedua adalah bahwa BPH dakwah, wakaf dan kajian Islam dalam melaksanakan programnya menerapkan fungsi-fungsi manajemen. Ketiga Hambatan dan Tantangan BPH dakwah, wakaf dan kajian Islam yaitu dana $\mathrm{BPH}$ dakwah, wakaf dan kajian Islam sudah dianggarkan dalam anggaran masjid dan biasa terkendala masalah itu karena persoalan komunikasi dan selain itu dinamika persaingan antara BPH dan pengurus yang lain serta belum dirumuskannya visi dan misi Masjid al-Markaz al-Islami Makassar.

\section{Implikasi}

Adapun yang menjadi Implikasi dari penelitian ini adalah (1) Pengurus $\mathrm{BPH}$ dakwah, wakaf dan kajian Islam perlu meningkatkan profesionalisme sehingga pengelolaan tanah wakaf di Masjid al-Markaz sebagai potensi ekonomi umat dapat terwujud. (2) Pengurus BPH dakwah, wakaf dan kajian Islam perlu memaksimalkan fungsi-fungsi manajemen yaitu: Planning (Perencanaan), Organizing (Pengorganisasian), Actuating (Pelaksanaan) serta Controling (Pengendalian dan Pengawasan) sehingga efesiensi dan efektivitas dapat tercapai. (3) Perlu adanya usaha untuk dapat menghadapai tantangan dan hambatan yang menghadang program/kegiatan BPH dakwah, wakaf dan kajian Islam. 


\section{DAFTAR PUSTAKA}

Abdurrahman, Abddullah Bin, Taudhih al-Ahkam Min Bulugh al-Maram, ter. Suparto, Thahirih, dkk., Syarah Bulughul Maram, Vol. V; Jakarta: Pustaka Azzam, 2006.

Amin, Muhammadiyah, Jurnal Ilmiah Keislaman Al-Markaz, Makassar: BPH Yayasan Masjid Al-MArkaz Al-Islami Jenderal M. Jusuf, 2005.

Arifin, Anwar, Jurnal Ilmiah Keislaman al-Markaz, Makassar: BPH Yayasan Masjid alMarkaz al-Islami Jenderal M. Jusuf, 2005.

Arikunto, Suharsimi, Prosedur Peneliti Suatu Pendekatan Praktik, Edisi refisi VI; Jakarta: Rineka Cipta, 2006.

al-Asqalani, Al-Hafiz Ibnu Hajar, Bulugul Maram min adillati al-Ahkām, ter. Abdul Rosyad Siddiq, Terjemahan Lengkap Bulughul Maram. Cet. V; Jakarta: Akbar Media Khasanah Buku Islam Rujukan, 2010.

Bungin, Burhan, Penelitian Kualitatif: Komunikasi, Ekonomi, Kebijakan Publick, dan Ilmu Sosial, Jakarta : Kencana, 2007.

Daradjat, Zakiah. Ilmu Fiqh, Jilid 3; Yogyakarta: Dana Bhakti Wakaf, 1995.

Departemen Agama RI, Al-Qur'an dan Terjemahannya, Bandung: PT. Syamil Cipta Media, $1428 \mathrm{H} / 2007 \mathrm{M}$.

Departemen Agama. Perkembangan Pengelolaan Wakaf di Indonesia. Jakarta: Proyek Peningkatan Zakat dan Wakaf Dirjen Bimas dan Penyelenggaraan Haji, 2003.

Direktorat Jenderal Bimbingan Masyarakat Islam dan Penyelenggaraan Haki, Perkembangan Pengelolaan Wakaf di Indonesia. Jakarta: Proyek Pengelolaan Zakat dan Wakaf, 2003.

Dirgantoro, Crown, Manajemen Stratejik: Konsep, Kasus, dan Implementasi. Jakarta: PT Gramedia, 2004.

Gazaly, Abdur Rahman dkk, Fiqih Muamalat, Edisi I; Jakarta: Kencana Prenada Media Groub, 2012.

Gitosudarmo, Indriyo, Manajemen Keuangan. Cet. II; Yogyakarta: BPFE, 2001.

al-Hawary, al-Sayyid Mahmud, al-Idārah al-Ushul wa usus al-Ilmiyah, Cet III, Kairo: Dār al-Kutub, 1976.

Jatmiko, RD., Manajemen Strategik, Malang: UMM Press. 2004.

al-Jaza'iri, Abu Bakar Jabir, Minhajul Muslim, terj. Mustafa 'Aini dkk, Minhajul Muslim: Konsep Hidup Ideal dalam Islam. Jakarta: Darul Haq, 2015. 
Kasdi, Abdurrahman. Wakaf Produktif Untuk Pendidikan. Yogyakarta: Idea Sejahtera, 2015.

Kriantono, Rachmat, Teknik Praktis Riset Komunikasi, dengan kata pengantar oleh Burhan Bungin, Edisi Pertama, Jakarta: Kencana, 2009.

Kurnia, Badan Hukum Sebagai Wakaf Menurut Kompilasi Hukum Islam, Makassar: Alauddin University Press 2013.

Majelis Ulama Indonesia, Fatwa Tentang Wakaf Uang Tahun 2002.

Mardani, Fiqh Ekonomi Syariah, Jakarta: Kencana Prenada Media Groub 2013.

Moleong, Lexy. J., Metodologi Penelitian Kualitatif, Bandung: Rosdakarya, 2001.

Mubarok, Jaih, Wakaf Produktif, Bandung: Simbiosa Rekatama Media, 2008.

Mubarak, Zulfi, Sosiologi Agama: Tafsir Sosial Fenomena Multi-Religius Kontenporer, Cet. I; Malang Press, 2006.

Mughniyah, Muhammad Jawad, Fighi Lima Mazhab, Jakarta: Penerbit Lentera, 2011.

Muhajirin, Noen, Metode Penelitian Kualitatif, Yogyakarta: Rake Sarasin, 1998.

Muhtadi, Asep Saeful dan Agus Ahmad Safei, Metode Penelitian Dakwah Bandung: Pustaka Setia, 2003.

Muzarie, Mukhlisin, Hukum Perwakafan dan Implikasinya Terhadap Kesejahteraan Masyarakat (Imlementasi Wakaf di Pondok Modern Darussalam Gontor), Jakarta: Kementerian Agama RI, 2010.

Narbuko, Cholid dan Abu Achmadi, Metodologi Penelitian, Cet. VIII; Jakarta: PT. Bumi Aksar, 2007.

an-Nasāi, Abī 'Abdu al-Rahmān Ahmād Bin Syu'aib bin 'Alì al-Syuhairi. Sunan anNasāi. ar-Riyāḍ: Maktabah al-Ma’ārif, 1996.

Newman, Willian H., Administrative Action, Prentice: Engliwood, 1975.

Pawito, Penelitian Komunikasi Kualitatif, Cet. I; Yogyakarta: PT Lkis Yogyakarta, 2008.

Purwanto, Ngalim, Ilmu Pendidikan Teoritis Dan Praktis, Bandung: Remaja Rosda Karya, 2006.

Qahaf, Mundzir, al-Waqf al-Islami; Tatawwuruhu, Idaratuhu, Tanmiyyatuhu, Cet. II; Syiria: Dar al-Fikr Damaskus, 2006. 
Qalyubi, Syihabuddin, dkk. Dasar-Dasar Ilmu Perpustakaan dan Informasi. Yogyakarta: Jurusan Ilmu Perpustakaan dan Informasi (IPI) Fakultas Adab UIN Sunan Kalijaga, 2007.

R.Terry, George dan Leslie W.Rue, Dasar-Dasar Manajemen, Jakarta: Bumi Aksara, 2010 .

Rasyid, Sulaiman, Fiqh Islam, Bandung: Sinar Baru Algensido 2014.

Reksohadiprojo, Sukanto, dan T. Hani Handoko, Organisasi Perusahaan: Teori, Struktur dan Perilaku, Yogyakarta: BPFE, 1999.

Rofiq, Ahmad. Fiqih Kontekstual dari Normatif ke Pemaknaan Sosial, Yogyakarta: Pustaka Pelajar, 2004.

Rohidi, Tjetjep Rohendi, Analisis Data Kualitatif, Jakarta: UI Press, 1992.

Said, M. Siraj and Lim, Hilary, Waqf (Endowment) and Islamic Philantrophy, United Kingdom: University of East London, 2005.

Sudjana dan Ibrahim, Penelitian dan Penilaian Pendidikan, Bandung : Sinar Baru Algesindo, 1989.

Sugiyono, Memahami penelitian Kualitatif, Bandung: Alfabeta, 2009.

Sule, Ernie Tisnawati dan Kurniawan Saefullah, Pengantar Manajemen, Jakarta: Kencana, 2008.

Usman, Husaini dan Purnomo Setiady Akbar, Metodologi Penelitian Sosial Cet. I; Jakarta: PT. Bumi Aksara, 2008.

Usman, Husaini, Manajemen: Teori, Praktik, dan Riset Pendidikan, Jakarta: PT Bumi Aksara, 2010. 